\title{
The Dialectic of Visual Arts Life in West Sumatra 1986-2003
}

\section{Nessya Fitryona}

Visual Arts Departement in the State University of Padang

Email: nessyafitryona@ymail.com

\begin{abstract}
West Sumatera is one of areas in the visual arts development in Indonesia. In 1980-1990s, there were found the presence data about installation of art and some alternative art works in art institutions and in public. The emergence that art works caused the struggle of the view of art practices in art society. That struggle seemed to thaw since emergence of Komunitas Seni Belanak (2003). This research explained the process of view of art practices that were occurred in West Sumatra which had changed from 1986 until 2003. This research used the concept of historical movement by Hegel dialectics theory and sociohistorical approach. The changing process of the art practices started from antithesis phase which was divided into two periods. The first antithesis period was the arrival of Agus Purwantoro (1986-1999). The second was the movement of IKIP Padang college students (1995-2003) and continued to the emergence of Komunitas Seni Belanak. The results of this study was the struggles in view of art practices in 1986 until 2003 was important as the transition period between the practices of modern art and the development of contemporary art in West Sumatra.
\end{abstract}

Keywords: dialectics, practice of art, modern art, contemporary art

\section{INTRODUCTION}

In the last two decades, the life of visual arts in West Sumatra has shown an increase their artistic activity. There has been development of form and appear various visual styles with exploration medium in art. It can be seen from art event that intense held such as an exhibition big reunion alumni SMSR perodically, exhibition artist from West Sumatra in Indonesian National Gallery, Bienalle Sumatra exhibition that organized since in 2012, until the exhibition in alternative art space appeared more and more. The art activities that have emerged, it can be observed many various tendency forms work and art practices that have changed significantly from previous developments. It has become an indication of a shift views in the practise of art.

In the 20th century, the development of visual art in this area appeared in modern arts. First time, the development of artwork identical with a characteristic visual mooi indië with naturalistic style. The existence of pattern of modern art began be variuos since establishment of art education institutions (Rosa, 2004: 11). The establishment of institution started with Kweekcshool in 1856 and Indonesiche Nederlands School (INS) Kayu Tanam in 1926. After that, In the sixties appeared two education institutions of art 
namely Institut Keguruan dan Ilmu Pendidikan (IKIP) Padang and Sekolah Seni Rupa Indonesia (SSRI) Padang. The style of visual arts especially naturalist painting in West Sumatra then development towards realists, expressive, decorative, kubistic and some style of the visual arts in other modern art more diverse including calligraphy to abstract. So far, artist still use conventional mediums for the artist expressions.

A different thing is seen in the dekade 2000s. Most artist who actively involved, especially the younger generation began to create artworks that has freedom of expression include the idea and medium in they art. They have worked art by mixing media of art, like installation, performance art, happening art, enviromental art, until using the latest technologies. The stretching that can be seen clearly in the emergence of Komunitas Seni Belanak (2003).

Shift a view in art practices of course that has not present by self. But there are things trigger, influence, and initiated happen a change of views in art practice. Such as Saidi said, a concatenation of the changes that occurred is a process history that runs dynamiclly and dialectically. According to that, journey of the art history which dialectical tinged with the emergence of a new art work with the spirit of entry even a radical which cannot be separated from motivation a tendency the dominant artwork present before. So, the changes that occurred in the life of art on a territory in the spectrum of history having potential tinged with various spirit entry to a tendency the development of that occurred earlier to an condition new development. It has a dialectical pattern (Saidi, 2008: 2).

Based on that statement, development of visual art in west sumatra around the end in year in 1980s showed a interesting fact. In mid-year 1980s, appear symptoms a visual art that considered "extreme" through installation art, performance art, happening art and variety of art that the dissolution of idiom-idiom form matra, no longer talk dwi matra, trimatra, and caturmatra (Rosa, 2006: 14). That phenomenon starts from the emergence of installation art called "Di sini Diam" in 1986 at surroundings campus IKIP Padang (Ganto, no.48/Th.VI/November 1995). The presence of work was followed up with the emergence of works performance art, happening art, and paintings use various media non conventional. At the time, the artwork was known as new form and different in emergence artwork in Padang even West Sumatra. In the next, the artworks appear have the potential as struck spirit condition in visual art practices that develops before in West Sumatra (Purnawati, 1994: 7).

Various responses that has emerged since the middle year 1980s indicated the a dialogue spaces. That the firts condition appeared not be taken for granted, but reap a range of conditions contradictory. In addition, the phenomenon that occured in the middle year 1980s has shown the process of conflict two the view of art practices. Two views consist of sight art practices of modern visual art who has long been developing in West Sumatra and views new possibilities in arts practice. It almost disappeared from view and became an interesting phenomenon to examined. 
If the art practise has been pulled into a straight line, the struggle condition of both views has been going on around 1980s has relation shifted to a condition that was more open, especially the reappearance Komunitas Seni Belanak in 2003. This research want to answer the question : how the process struggle occurred in the life of visual art within 1986 and 2003 till occured changes the practices of art.

\section{METHODS}

The research is qualitative study with descriptive analysis and sociohistorical approach. Data obtained from interviewing the people who were involved in art practices in research time, the field observed behavior art practise include perception, motivation, the act of interviewer that involved with art development in 1986 until 2003 (primary data), examining documents in newspaper clippings, documents activity and artworks (secondary data). The problems in this research dissected with dialectical theory G.W.F. Hegel. According to Hegel's theory, history move forward with in a dialectically in landscape idea, the difference of time the development of that runs continuously in phase thesis, antithesis, and yielding synthesis that show the new existence. Then, the new existence will return to the through movement dialectically (Mudhofir, 2001: 43).

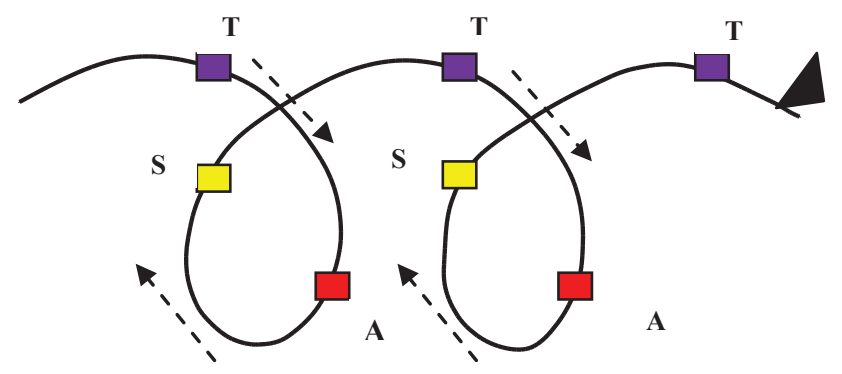

Where:
$\square \mathrm{T}=$ Thesis
$\square \quad \mathrm{A}=$ Antithesis
$\square \quad$ S $=$ Synthesis

The level of idea in dialectical Hegel perspective has a ties like the collision of views formed in the life of visual arts in West Sumatra in around the end of year 1980s until the beginning of the year 2000s. The thesis phase can be seen from developmentally a historical which show focused a view, or concepts a framework for the creation of artist, and shows a ideology thought art or culture widely (Burhan, 2013 : 121). Then the thesis has the potential to cause an idea that is opposition to that which is called antithesis. This happened because that reality is represented on an idea first demanded that reality (AshShadr, 1993 : 151). Thesis and antithesis are reconciled in form of a new affirmation. That is aufgehoben. Aufgehoben have three meaning: firts, exclude or deny, thesis or antithesis 
eliminated. Second, caring for storing or preserving contradictions thesis and antithesis. Third, put the thesis and antithesis in a higher level.

\section{RESULTS}

\section{The View of Modern Art in West Sumatra Before 1986}

Movement of dialectics started from the big ideas or large narrative as thesis. The large thesis can be seen from developmentally a historical which show focused a view, or concepts a framework for the creation of artist, and shows a ideology thought art or culture widely (Burhan, 2013 : 121). Before the entry of the influence of the modern art in West Sumatra as with the presence of the dutch colonial that carries modern culture in the era of colonialism, visual art practise still known traditionally to the production of objects of art collectively and anonymous. Such carvings in Rumah Gadang, songket, pottery, and other handicrafts products.

Contiguity the modern art in West Sumatra stems from an education art founded the Netherlands government that imparts concepts and universal values, including in the field of Western art. That is Kweekschool. This school then bring out an artist named Wakidi who succeeded impact on the lives of the visual arts in West Sumatra with pointedness pattern naturalistic in paint (Rosa, 2006 : 9). Most profession artist who begin to appear having a tendency representation objects of natural scenery at West Sumatra in landscape, calculating, and scenic. Art works that appear in accordance catch visual with to cultivate techniques be standardized. There are replicate work paint, make perspective color, meticulous technique, subtlety in processing form and color same as mooi indië painting who developed in Indonesia (Rosa, $2004: 8)$.

Later, diversity pattern the visual arts modern richer with growing some educational institutions that has an interest in visual art, namely Indonesich Nederlandsche School Kayu Tanam (1926), majors of visual arts IKIP Padang (1963), Sekolah Seni Rupa Indonesia /SSRI (1965). The diversity the dynamic with introduction various forms art work as sculpture, graphic art, kriya, in addition to the art of painting that develops dominant.

The existence of many institutions the art plus the role of artist who has shown tendency toward the modern art, then influence in the perspective of in art work and art practices that is embedded in the middle of the 20th century. Themes that often presented still tending to rest upon of natural scenery West Sumatra in subjective presented in exotic and lyrical covering activity social life, the figure of portrait, still life to religious themes as calligraphy and a small number is leading to criticism social. That ideas represented into various pattern universal modern art adapted of teachings of West such as realists, impresif, expressive, decorative to abstract in beside still like for pattern realists and naturalist in artists artwork. That can be seen from its tendency art works artist in year around 1970 to 
eliminated. Second, caring for storing or preserving contradictions thesis and antithesis. Third, put the thesis and antithesis in a higher level.

\section{RESULTS}

\section{The View of Modern Art in West Sumatra Before 1986}

Movement of dialectics started from the big ideas or large narrative as thesis. The large thesis can be seen from developmentally a historical which show focused a view, or concepts a framework for the creation of artist, and shows a ideology thought art or culture widely (Burhan, 2013 : 121). Before the entry of the influence of the modern art in West Sumatra as with the presence of the dutch colonial that carries modern culture in the era of colonialism, visual art practise still known traditionally to the production of objects of art collectively and anonymous. Such carvings in Rumah Gadang, songket, pottery, and other handicrafts products.

Contiguity the modern art in West Sumatra stems from an education art founded the Netherlands government that imparts concepts and universal values, including in the field of Western art. That is Kweekschool. This school then bring out an artist named Wakidi who succeeded impact on the lives of the visual arts in West Sumatra with pointedness pattern naturalistic in paint (Rosa, 2006 : 9). Most profession artist who begin to appear having a tendency representation objects of natural scenery at West Sumatra in landscape, calculating, and scenic. Art works that appear in accordance catch visual with to cultivate techniques be standardized. There are replicate work paint, make perspective color, meticulous technique, subtlety in processing form and color same as mooi indië painting who developed in Indonesia (Rosa, $2004: 8$ ).

Later, diversity pattern the visual arts modern richer with growing some educational institutions that has an interest in visual art, namely Indonesich Nederlandsche School Kayu Tanam (1926), majors of visual arts IKIP Padang (1963), Sekolah Seni Rupa Indonesia /SSRI (1965). The diversity the dynamic with introduction various forms art work as sculpture, graphic art, kriya, in addition to the art of painting that develops dominant.

The existence of many institutions the art plus the role of artist who has shown tendency toward the modern art, then influence in the perspective of in art work and art practices that is embedded in the middle of the 20th century. Themes that often presented still tending to rest upon of natural scenery West Sumatra in subjective presented in exotic and lyrical covering activity social life, the figure of portrait, still life to religious themes as calligraphy and a small number is leading to criticism social. That ideas represented into various pattern universal modern art adapted of teachings of West such as realists, impresif, expressive, decorative to abstract in beside still like for pattern realists and naturalist in artists artwork. That can be seen from its tendency art works artist in year around 1970 to 
different from the previously had form and themes that negation a tendency developing in West Sumatra. It has resulted in Agus Purwantoro and his gait as walk alone and separate from its symptoms art.

The period of arrival of Agus Purwantoro started in 1985. He has came to Padang, West Sumatra to meet the opportunity given the Rector of IKIP as teachers in visual arts department. He is an artist graduates from Akademi Seni Rupa Indonesia (ASRI) Yogyakarta 1977. A form of negation in antithesis phase in the development of visual art in West Sumatra starts with desire Agus to break down reliability view academic still riveted on the concept of art practices that still conventional and stiffening in West Sumatra at that time. Contention resulted in negation of new bids to the shape of and the pattern think to seen the art practise as something free and in spite of elements reliability. Struck the new started of the appearance of his first artwork, namely art installations "Di Sini Diam". Its artwork created in 1986 on south of campus IKIP Padang. That art instalation consist of pile of chairs that have been worn.

The emergence of experimental artworks, art installation, performance art and happening art in art practice offered Agus Purwantoro then have a pro and contra response. Response was triggered from the shape of art work and difference in the use of material unusual and distinct. That artwork such as art instalation "Di Sini Diam" (1986), art instalation "Eling" (1994), art instalation "Persembahan" (1995), art instalation "Kambing Hitam" (1996), art instalation "Nasib Nyamuk" (1994), art instalation and happening art "Bumi GonjangGanjing" (1998). Most of his work had the characteristics of work use of language estetik is kitsch. He has built simulate and copying elements the style of high artistic or object daily for the benefit of his artwork. For example he use objects like the seat of daily, used goods as cans, damaged table, cardboard, an envelope, newspaper, a broom stick, clothesline, until materials the kitchen as vegetables.

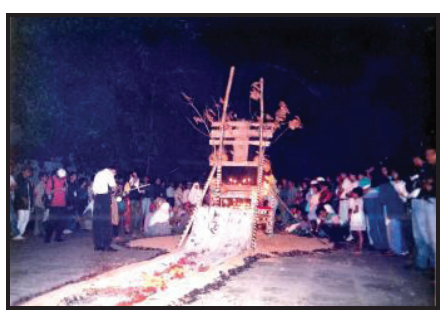

Art instalation by Agus

Purwantoro, Eling, at Taman Budaya Padang (1994)

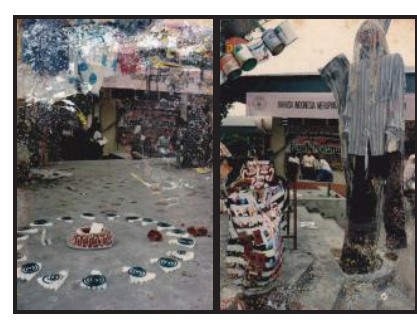

Exhibition art instalation Nasib Nyamuk by Agus Purwantoro at yard office's FPSB IKIP Padang (1995)

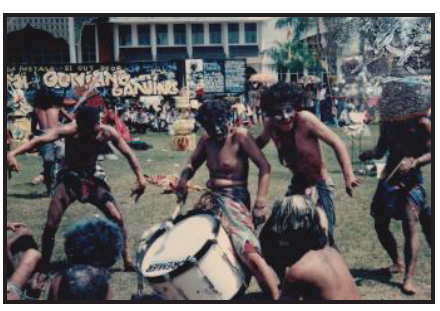

Action happening art in Bumi Gonjang-Ganjing activity in 1998 at soccer field's IKIP Padang

Hauser said, phase antithesis characterized by appearance of the power of a force new productive, an effort glory new, a technique achievement, individual talent, or readiness 
with the effort to the condition production that is, a form of government, a legal procedures, the concept of moral, and norma is the old way, a penerobosan what happened between an ancient new and repetition adaptation the need, and by a necessary condition (Hauser, 1982 : 340). The phenomena the works of art installation, performance art, and art forms experimental other, as a result negation done Agus Purwantoro. It has links while the effect on the social condition political that was going on the time as a condition of social required in that phase antitesis namely Orde Baru (1966-1998). Social conditions as a result in Orde Baru that has been in turmoil in Indonesian goverment responded by Agus Purwantoro by covering the various criticism in secret behind his artwork.

Themes in the art work of another artist in West Sumatra at the moment most is still in the theme condition Minangkabau custom, sociocultural of life, spiritualities, and exotic nature. In the side they have attempt to find novelty and originality in artwork with the emergence of various pattern and personal style in painting sporadiclly. In addition, social condition artists in West Sumatra about 1980s until 1990s most still tied to the impact of from a condition of being those experienced who have had an impact on art activity. Impact on the difficulty of to give exhibitions in Taman Budaya Sumatra Barat, expensive tools of painting, there is no artist who dare the total of art work and plunge professionally in the life of arts, and looking at other alternatives in artist expression.

Various negations Agus Purwantoro done in his art works and his activity in art practices, including also terms of teaching system which he apply to his college students in IKIP Padang. That teaching system having the style different from formal academic which structured, and discipline. Agus have a different perspective to art practice of likeness in the application of the college students experiences in the art academic. Subjectivity from born of what he saw and might feel toward art practices in West Sumatra and within academic make it moved to change views and paradigm artist who did not have greget for him. While for in the academic, he realized that college students when that took enlightenment and something new to satisfy a feeling of them in art (Agus Purwantoro, interview on august 4th, 2016). That twist around in educating college students in art to use format that is more open and not only chase on view be standardized academic formally, structured, and established.

Agus having views the artwork is not quite turned on within the art society and in the art academic. So, he have required extracurricular activities which performed by a college student and society which are pertaining to expand the scope of art practices and consumption art in general public. That has been positive for students concerns. According to Agus's college students will be trained to organize, and always an innovator, motivator in the creative by various events he do inside campus or in public place which is in direct contact with the society (Agus Purwantoro, interview on january 26th, 2015). 
Various alternatives material attempted directed Agus in lecture also is a solution of which to help college students to make artwork without having to buy oil paint which is considered to be expensive bags less for them. While in the expression it is not as an obstacle. So that in agus purwantoro period of teaching at the visual arts departement at IKIP Padang, more students tend produce the experiments artworks with alternative media. Those activities received positive responses. Some from them feel motivated and be passion to make something new as they expression in art.

Before the arrival of Agus Purwantoro, art works college students was focused on control engineering and formal conventional forms. That is basic competence the visual arts in academic. So it was still formed strong convention of modern art in campus. Ripeness technique is strongly accounted especially on the form of realists and suitable to the character objects based catch eyes. Transfer the science and understanding shape view towards the students before the existence of Agus Purwantoro also cannot be separated from the existence of figures had played a role in the visual arts teaching in IKIP, as Idran Wakidi, Muzni Ramanto, Achyar Sikumbang, and some other senior lecturer and having strong pattern in art works which naturalistic and realistic styles.

A method of think dialectical used hegel as the fundamental principle explain the various existence and development of reality in the domain of idea. Gait Agus Purwantoro in West Sumatra in idea and the idea to view freedom to experiment with and expression and anti reliability in art practices of apparently not is fully supported. That can be seen from Agus Purwantoro is single artist in West Sumatra when it was actively involved with experimental art. In 1999, he chosen return to Java and teaching in Universitas Sebelas Maret, Solo. Moving Agus Purwantoro cameback to Java, causing activity experimental art almost lost. Antithesis done Agus Purwantoro, in the end of the coming produce synthesis the return of view long to modern art.

After Agus Purwantoro and his mind exist in West Sumatra, next ignitd some college students doing different art practise with benchmark convention into standard assessment campus. A groove motion the process dialectics ongoing relentless throughout history. Synthesis resulted can be the new which bring out to new antithesis and both make peace form a new synthesis. So that the dialectical Hegel is described with the motion of spiral (Mudhofir, 2001 : 43). The movement of spiral created of the dialectics pattern between the thesis, antithesis, and its synthesis then back into the thesis who moves forward and progressive. Occurred when the dialectics process coming of Agus Purwantoro, and yielding synthesis back the view of modern art which conventional especially in campus. That next, trigger reaction antithesis of among collage students. 
Phase antithesis II : A period of movement of college students IKIP Padang 19952003

In the period of the movement of college students appear the seeds of progressive movement desired a change the views on art practices. That is in which movement antithesis done Agus Purwantoro in the end. The art practices that occured in West Sumatra became an object observation among college students at that time. Direct observation are result of discontent against symptoms and art practices that happen around them. Based on they subjective observations, development the life of visual art in West Sumatra haven stagnantly especially that become trigger the beginning were art practices around campus in visual arts departement in IKIP (Iswandi, interview on May 28th, 2015).

Phase antithesis on the movements of college students start thinking critical and sceptical towards matter and visual art practices that given in art instutions. This in turn consciousness raising self-conscious of their role as young artists generation and determine the direction development of visual art in West Sumatra in the next. Self-awareness then according to Hegel forming ideas or structure thought to refuse or negation great idea art practices on art institusions considered disrupting the development of discourse and art practices by a new tendency.

Openness against discourses and information is also concerned with the beginning of the year 2000s marked the entrance of the reign of Indonesia in Reformation era, has allowed opportunities society in free speech and openness to the current global discourse in line with progress in the field of technology. This also resulted in was so easy to be traced and discourse known information about the development of the art of both national until global stimulates thinking critical of a fact and increasing needs of information widely among younger generation.

A period of the movement of students start was initiated in the 1995. Then students beset manic to new discourse they can from outside environment West Sumatra by the fact that they observe based on symptoms and art practices in West Sumatra. It is also accompanied by desire a group at that time to have the opportunity follow activities exhibition (Iswandi, interview on May 27th, 2015). Discourse development of circulating in this area are still localized. They start looking for reference and discuss relating to discourses in the arts of coming from outside West Sumatra and comparing. Discourse and references on the development of the visual arts outside West Sumatra come one of which is through relation between alumnus SSRI/SMSR that continued education to Java especially in Yogyakarta.

Some of students who enough critical was experiencing shifting patterns think or view based on discourse and art practices that they get from outside campus. There is a feeling of dissatisfaction students to campus triggered by several things in the campus, such as not the availability of facilities to university students the visual arts especially of the art of 
painting studios of painting conducive to students practicing paint on campus. This might impact on less facilitate space college students to work on campus. In another hand, West Sumatra Cultural Park has not been too open to receive exhibition activities from art students. At that time, they as one of art instution that provide space of art exhibiton in more likely to open opportunities to senior artist.

About 1996, some students of visual arts departement in IKIP force 1995 and some force on it beginning to form an association of which was started from a boarding houses. The association on Srigunting street in Air Tawar area, in Padang, near from campus. About 1996 art students often gathered in location, then the assembly finally named "Kreatif group" (Iswandi, interview on may 28th, 2015). The name of the group comes from a place boarding houses, namely "Wisma Kreatif'. Some student who joined in the group still always conduct the activity of making work of art in order duty college together.

Sometimes explore techniques in art work outside duties college.

After that, they signed a house in Gajah street, Gang Belanak still in the area of about Air Tawar Padang. The students who formerly gathered at Wisma Kreatif, moved to rented in Gajah street and joining a sodality named "Kantau". The name of "Kantau" as a association of being appellative familiar after they made a mural with writing "Kantau" in one part the outer wall boarding houses. Group Kantau intend to made activities of art like play, negation a condition they felt on campus to shades formal art, bound and stiff and having views still closed at art practice with new various trends. Students who joined in Kantau groups of them Irwandi, Rajudin, Iswandi, Erlangga, Syahrial, Harpan, Ardianto, Ibrahim, Ferdi, Johor and students other often converging on that place which of them become an younger artist famous in West Sumatra.

Kreatif group and Kantau originally begins with intention gathered and discuss together develop into an effort tried to fight back of limitations that are had happened in the life of visual arts in West Sumatra. This limitation covering facilities for exhibition, exchange of information, and media publication art activities. Discourse of this was obtained through various a medium and theory art books have consumed some college students, reference catalog exhibition. It is finally trigger critical attitude and awareness against gaps of development of art that was going on with that occurs outside the district. After forming informal group as a forum to discuss and exploration artwork and the last they have agreed to make a container that more large and complex namely form an artcommunity.

About 1996-1999, the movement of students has still in the collection discourse and information to the development of the visual arts outside West Sumatra, and discuss. Group of students formed has not bring up struck meaningful and looked in reality as do activities exhibition or were art work in public space. It was because students do not have the power to do that. Then with started a shared interest simple, which is to bridge their artwork to reach the apresiator, through the agreement of \pm 25 younger artists and college 
students who held about the year 2002, so formed a community was answering they uneasiness (Ibrahim, interview on january 24th, 2016). That community is Komunitas Seni Belanak.

That community next inaugurated and declared in 2003 and opening firts exhibition titled "Firts Step" in Sarasah Gallery. Sarasah Gallery is one of private galery which has been built in West Sumatra. The art works of Komunitas Seni Belanak that presented and the way to art practices offered to the public art and society in general by this community is both shown the development that more progressive in the life of the visual arts in West Sumatra. The new possibility presented in the form of work alternative and experimental, and mixed media.

Challenging climate the visual arts in West Sumatra which in condition that is complex, Komunitas Seni Belanak successfully position itself bring the development of life the arts in West Sumatra more open and majesty. They hava done a lot of format activities varied with forms the arts which more innovative. They have done the next capable of forming and build elements art world required in build climate the visual arts such as an author and younger curator, media of knowledge distribution about art and forth of their members. In his zeal there are also discussion activities, workshop, the screening, collaboration an art project and some exhibition art and training writing critizing art in campus and outside campus. Komunitas Seni Belanak also manage to build social network which began open to publish all their activities.

In accordance with the goal at first which to open discourse and information from outside West Sumatra, they have opened up the opportunity to the cooperation with the art community in Indonesia such as Komunitas Taring Padi, Cemeti Art foundation, and Ruang Rupa Jakarta. Indeeed, they can building even cooperation with an artist from Australia, namely Alexandra Croby, in the their arts even is "Art Day is Today" in 2006. Through activities those which are open and flexible, they were also able to promote the art into environment public to extend and build appreciation of the society toward arts. Activities are "Get The Book" held in Tunggul Hitam society in Padang, the existence of community in 2004. In addition, they also form mutual relation and bring discourse by inviting any figure having a role in sphere the visual arts in Indonesia as curator and artists from several areas the base the visual arts of them Komunitas Seni Belanak ever invited curator, namely Kuss Indarto in the exhibition prime they "Firts Step" (2003) and Asmudjo Irianto as curator in exhibition "Apresiasi urban” (2008).

The ends of the movement of college students 1995 - 2003 as younger artists next shown a movement heading to the development of that is more open in view art practices in West Sumatra. It was accompanied by entering and began strengthening discourse the contemporary art in this region. This condition is phase synthesis characterized the seconstructions which done by Komunitas Seni Belanak on climate the life of visual arts in 
West Sumatra before. The community up with its values of art more bring the face contemporary art. The condition aufgehoben as a result of the stage synthesis (become). Aufgehoben in the concept of thought dialectics Hegel that made thesis and an antithesis in which contention into a unified later appointed to the situation of higher. And, the modern art in art practices is conventional which remains the large in the life of the visual arts in West Sumatra developing in tandem with a new tendency possibility which attended the art practices of contemporary art favorite of by mostly on young artist generation. This seems visually of activities of an exhibition present in West sSumatra in 2000 to the current.

Hegel said, every new generation in scope history that run in dialectical can assume himself as the destroyer, conservationists, and falsifies a culture which inherited from a predecessor (Aiken, 2002: 85). So, in the movement has done college student who joined in Komunitas Seni Belanak as artists new generation is a condition falsifies in arts practices in West Sumatra to the development of that is more open and follow the developments discourse the art. It was said to be falsifies, because of they supported not cut off tradition naturalistic and landscape they predecessor to activity arts practices done they members, on the other hand they also adopt arts practices of contemporary openly in they art work.

In West Sumatra, that shift can be seen from the activities exhibition where senior artist and younger generation join shown pattern and raise the issue of contemporery both social, political, and economic critics. In addition, shift the notion of arts practices also changes art practices senior artists in West Sumatra about 1990 down generation to forms that are better innovative and having exploration by a new tendency. The phenomenon of art also increased in the area of cooperation the exhibition, not only located in West Sumatra or Sumatra, but also held nationally into the event exhibition more established.

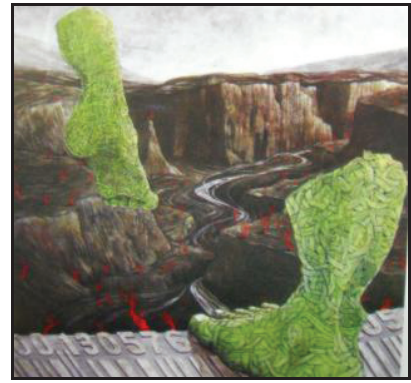

Iswandi "Menjemput Hijau" (2006)150 x 150 $\mathrm{cm}$, Acrilic on canvas

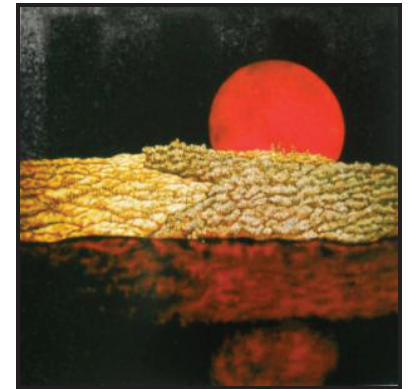

Nasrul Palapa "Pancang Emas di Batas Cakrawala II", $145 \times 145$ $\mathrm{cm}$, mix media

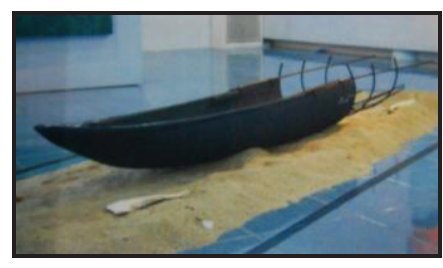

Jon Wahid "Takatuang", $290 \times 50 \times 40 \mathrm{~cm}$, mix media 


\section{CONCLUSION}

In 1986 happened phase antithesis in arts practice in West Sumatra marked with the emergence of experimental art works like art installation, performance art, happening art which negation reliability thesis towards the notion of convention in modern art practices that develops before. Period of 1986-2003 is a transition between views of convention to art work and practices in modern art to art works and practices contemporary art in West Sumatra. That time having two important point, firts point the arrival of Agus Purwantoro as grow struggle the view of art practices in West Sumatra and shows the starting the entry of the phenomenon apractices in contemporary art in the life of visual arts in West Sumatra. Second important point is emergence Komunitas Seni Belanak with their role in open discourse of contemporary art as milestone early leads life the visual arts which move more progressive in an activity and arts practices among artists in West Sumatra.

\section{REFERENCES}

Aiken, Henry D. 2002. Abad Ideologi. Yayasan Bentang Budaya: Yogyakarta.

Ash-Shadr, Muhammad Baqir. 1993. Falsafatuna. Mizan: Bandung.

Burhan, M. Agus. 2013. Seni Lukis Indonesia Masa Jepang Sampai Lekra. UNS Press:

Semarang.

Mudhofir, Ali. 2001. Kamus Istilah Filsafat dan Imu. UGM Press: Yogyakarta.

Saidi, Acep Iwan. 2008. Narasi Simbolik Seni Rupa Kontemporer Indonesia. Isacbook: Yogyakarta.

\section{Newspaper Kliping}

Ade, (26 Juni 1988), "Seni Rupa IKIP Padang Berperan di Pariaman”, Semangat Minggu. Anonim, (24 November 1994), "Dua Lukisan Besar Muncul di Dinding Pasar Borong Padang", Haluan.

Anonim, (-- November 1995), “Lebih Dekat dengan R.Agus Purwantoro, Sosok Seniman yang Gelisah", Ganto.

De, A.A Lin, (20 April 1998), "Dari Kadispara ke Depparsenibud", Singgalang.

Efix, (20 November 1996), "Peta Lukis Biennale Menetap", Kompas.

Gazali, Ahmad, (13 Januari 2003), “Taman Budaya Ditikung Jalan”, Singgalang.

Hadinata, Kurnia, (7 September 2003), "Melongok Geliat Perupa Belanak : Menapak Jejak untuk Awal Sebuah Perjalanan”, Singgalang.

Ikhirma, Abrar Khairul, (9 Januari 1996), "Ketika Pelukis Sumatera Mencari Pengakuan", Haluan.

Sumbar", Haluan.

Koto, Viandri, (Edisi No.26/ Tahun IV/Januari 1994), "Pagelaran 'Fun Art", Ganto.

Ramanto, Musni, (12 November 1974), "Komunikasi Sebuah Karya Seni (1)", Haluan. , (19 November 1974), "Komunikasi Sebuah Karya Seni (2)", Haluan. (11 Oktober 2006), "Menapak Jejak-Jejak Seni Patung, Patung Karya

Seni 3 Dimensi yang Berbicara Lewat Massa dan Ruang"(2), Haluan.

Muharyadi, (15 Februari 1994), "Sosok Pelukis : Agus Purwantoro, Berakar dari Seni Tradisi", Haluan 